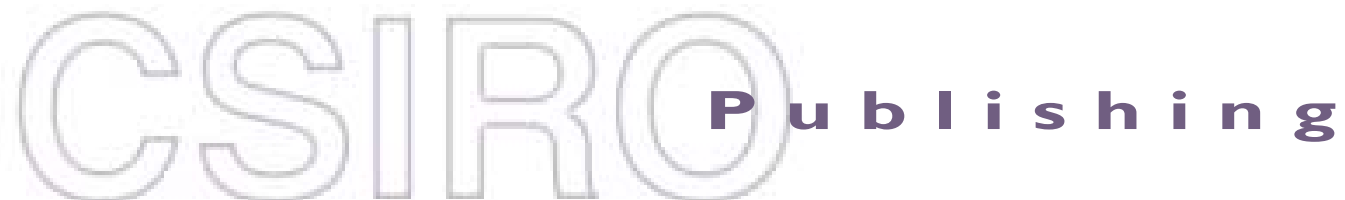

\section{Australian}

Journal of

Agricultural

Research

(C) CSIRO 2002

A journal for the publication of original contributions

towards the understanding of an agricultural system

\section{All enquiries and manuscripts should be directed to:}

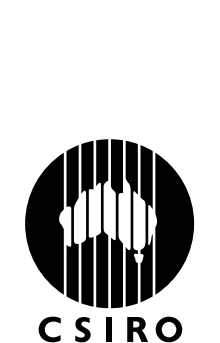

Australian Journal of Agricultural Research

CSIRO Publishing

PO Box 1139 (150 Oxford St)

Collingwood, Vic. 3066, Australia

Telephone: +6139662 7628

Fax: +6139662 7611

PUBLISHING Email: publishing.ajar@csiro.au

Published by CSIRO Publishing

for CSIRO and the Australian Academy of Science

www.publish.csiro.au/journals/ajar 


\title{
The production and storage of a fermentor-grown bacterial culture containing Synergistes jonesii, for protecting cattle against mimosine and 3-hydroxy-4(1H)-pyridone toxicity from feeding on Leucaena leucocephala
}

\author{
A. V. Klieve ${ }^{\mathrm{AC}}$, D. Ouwerkerk ${ }^{\mathrm{A}}$, A. Turner $^{\mathrm{A}}$, and R. Roberton ${ }^{\mathrm{B}}$ \\ ${ }^{A}$ Queensland Beef Industry Institute, Agency for Food and Fibre Sciences, Department of Primary Industries, \\ Animal Research Institute, 665 Fairfield Road, Yeerongpilly, Qld 4105, Australia. \\ ${ }^{\mathrm{B}}$ Brian Pastures Research Station, Queensland Beef Industry Institute, Agency for Food and Fibre Sciences, \\ Department of Primary Industries, Gayndah, Qld 4625, Australia. \\ ${ }^{\mathrm{C}}$ Corresponding author; email: klievea@dpi.qld.au
}

\begin{abstract}
The leguminous shrub Leucaena leucocephala (leucaena) is widely used as a forage species for cattle in tropical agriculture. However, leucaena contains the toxic amino acid mimosine. Both mimosine and its primary ruminal degradation product 3-hydroxy-4(1H)-pyridone (DHP) are toxic and their accumulation in the animal's system results in hair loss, reduced liveweight gain, and goitre. The ruminal bacterium Synergistes jonesii is known to degrade these compounds and inoculation of the bacterium into the rumen protects cattle against mimosine and DHP toxicity. We report on the development, production, and storage of an in vitro, fermentor-based, mixed bacterial inoculum, which includes $S$. jonesii, for administration to cattle. This technique may be applicable to the production and delivery of other live, anaerobic, bacterial inocula for use in animal agriculture.
\end{abstract}

Additional keywords: rumen, beef cattle, PCR assay.

\section{Introduction}

The leguminous shrub Leucaena leucocephala (leucaena) is widely used as a forage species for cattle in tropical agriculture (Shelton 1998). In subtropical Queensland, leucaena has been used commercially to increase liveweight gain in cattle for the past 15 years (Addison et al. 1984; Wildin 1985). Although leucaena has the potential to greatly improve beef production in Queensland when fed to cattle as the predominant dietary component (Quirk et al. 1988, 1990), it also contains the toxic amino acid mimosine. Both mimosine and its primary degradation product 3-hydroxy4(1H)-pyridone (DHP) are toxic (Hegarty et al. 1964; Hammond 1995) and DHP can cause hair loss, reduced liveweight gain, and goitre (Hegarty et al. 1964; Hegarty et al. 1976). This toxicity limited the use of leucaena in Australia until the early 1980s when Jones (1981) reported the absence of toxicity when leucaena was fed to goats and cattle in Hawaii. The low urinal DHP concentrations in these animals suggested that they could degrade mimosine and DHP, and Jones (1981) hypothesised that a 'biological' solution to leucaena toxicity was possible. Subsequently, mixed bacterial cultures derived from the rumen contents of
Hawaiian goats were transferred to cattle in Australia and shown to confer complete protection from clinical disease (Jones and Megarrity 1986).

The bacterium responsible for mimosine and DHP degradation has been isolated in pure culture, characterised, and shown to be a novel ruminal bacterium, named Synergistes jonesii (Allison et al. 1992). Currently, this is the only species of ruminal bacterium known to have the ability to degrade DHP (Allison et al. 1992). Inoculation with rumen contents containing this bacterium protects against mimosine and DHP toxicity in ruminants (Hammond 1995). Furthermore, the bacterium is positively selected for in leucaena-fed animals and rapidly spreads to uninoculated animals within the herd (Quirk et al. 1988, 1990; Hammond 1995). At the practical farming level this means that with appropriate management, once the bacterium has been introduced to a property, it can be maintained indefinitely.

Since these early discoveries both the CSIRO and Queensland Department of Primary Industries have supplied ruminal fluid, from previously inoculated steers continuously fed on leucaena/grass pastures, to beef cattle producers who wished to exploit the nutritive advantages of feeding leucaena. However, maintaining rumen-cannulated 
steers permanently on leucaena solely for this purpose was expensive in terms of veterinary, feeding, and handling costs.

This paper reports on the development, production, and storage of an in vitro, fermentor-based, mixed bacterial inoculum, which includes $S$. jonesii, for administration to beef cattle to prevent mimosine and DHP intoxication while feeding on leucaena.

\section{Materials and methods}

\section{Fermentor operation, inoculum production, and storage}

A diagram outlining the processes involved in operating the fermentor and the production of inoculum is presented in Fig. 1.

The basic operation of the fermentor (Mini Jarfermentor M-100; Tokyo Rikakikai Co. Ltd) was modified from that reported previously (Miller et al. 1997). Fermentation commenced with a starter culture (see below) being added to $1800 \mathrm{~mL}$ of a rumen fluid (RF) medium (Klieve et al. 1989), modified by the reduction of rumen fluid, yeast extract, and peptone by $50 \%$. At commencement of the fermentation, $30 \mathrm{~g}$ of coarsely macerated (Waring blender on low setting, $6 \times 5$-s pulses) leucaena leaf was added as substrate for the fermentor. Leucaena leaf was stored frozen at $-20^{\circ} \mathrm{C}$ until maceration and use. If the macerated leaf was not to be added to the fermentor immediately, it was refrozen until required. On the second day of fermentation the amount of macerated leucaena leaf added was reduced to $15 \mathrm{~g}$, and each day thereafter $10 \mathrm{~g}$ was added to the fermentor. Each day, half of the fermentor liquid was removed and replaced with anaerobic culture medium (Klieve et al. 1989) that had been further modified by the removal of most nutrients to leave a balanced salts solution, as reported by Miller et al. (1997). It was at this time that the macerated leucaena leaf was also added to the fermentation. The fermentor vessel was maintained at $39^{\circ} \mathrm{C}$ and continuously bubbled with a mixture of $\mathrm{CO}_{2}: \mathrm{H}_{2}(95: 5 \mathrm{v} / \mathrm{v})$ to maintain anaerobic conditions.

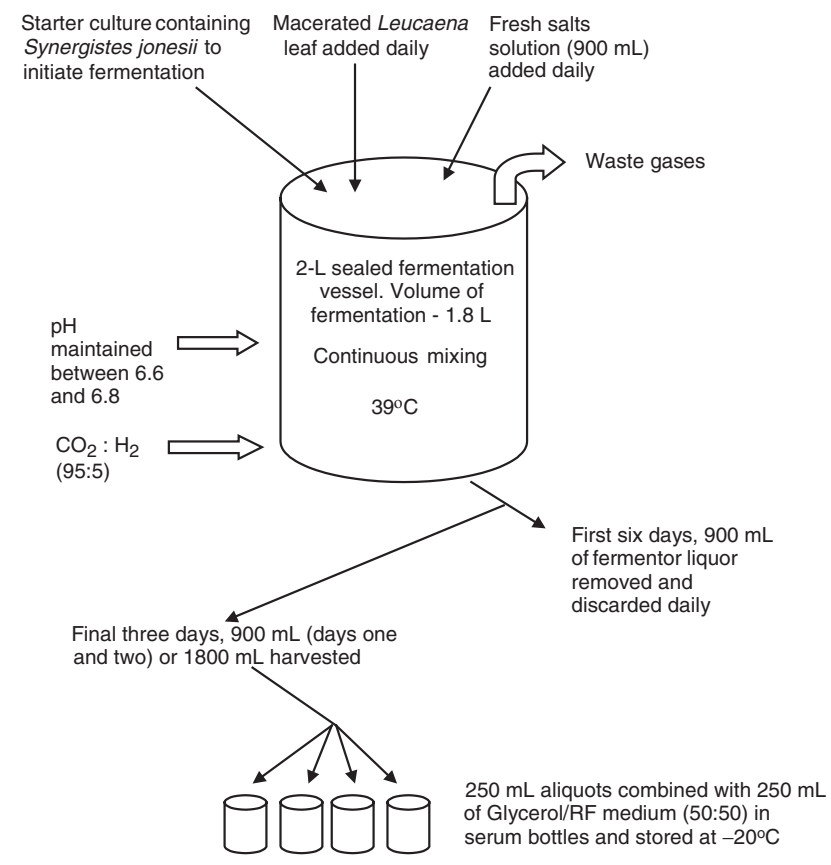

Fig. 1. Diagrammatic representation of the fermentation process.
The initial starter cultures used were derived from rumen fluid collected from Bos indicus cross steers that had been kept solely as a source of $S$. jonesii inoculum at Brian Pastures Research Station. Ruminal fluid was collected and stored for use as starter cultures in a similar manner to that reported previously for rumen fluid sample collection and analysis (Klieve et al. 1998). Briefly, 50-mL aliquots of rumen contents, strained through a double layer of nylon gauze, were injected, using a needle and syringe, through the septum of a $100-\mathrm{mL}$ serum bottle (Wheaten) into $50 \mathrm{~mL}$ of an anaerobic solution comprising $50 \% \mathrm{RF}$ medium and 50\% glycerol (Univar). This material was frozen at $-20^{\circ} \mathrm{C}$ and stored until required. A $25-30-\mathrm{mL}$ volume of this starter was used to initiate fermentation. When supplies of this starter were exhausted, it was replaced with harvested fermentor contents prepared and stored in the same manner. A $100-\mathrm{mL}$ volume of this starter was used to initiate fermentation.

Fermentation was undertaken over a period of 9 days, with inoculum being harvested over the final 3 days. On each of the first 2 days of harvesting, $1 \mathrm{~L}$ was removed and $250-\mathrm{mL}$ aliquots were mixed with $250 \mathrm{~mL}$ of the anaerobic RF medium/glycerol (1:1, as above) solution in $500-\mathrm{mL}$ serum bottles. On the final day the entire contents of the fermentor were harvested and processed as above. The serum bottles were frozen at $-20^{\circ} \mathrm{C}$ prior to shipping on dry ice to Brian Pastures Research Station. They were then stored at $-20^{\circ} \mathrm{C}$ until required by beef producers.

\section{Mimosine and DHP degradation}

The presence of mimosine and DHP was detected by colorimetric assay (Allison et al. 1990).

To gauge the ability of the fermentor-produced inoculum to degrade mimosine (and DHP), six 10-mL aliquots of fermentor liquor were removed from the fermentor on the final day of fermentation and each was placed in a sterile Hungate tube. The headspace was gassed with $\mathrm{CO}_{2}: \mathrm{H}_{2} 95: 5$ and the tubes sealed. To 2 tubes, $1 \mathrm{~mL}$ of $5 \mathrm{~mm}$ mimosine (Aldrich Chemical Co., WI, USA) was added, to another 2 tubes $1 \mathrm{~mL}$ of $15 \mathrm{~mm}$ mimosine was added. No additional mimosine was added to the remaining 2 tubes. After addition of mimosine, $0.25-\mathrm{mL}$ samples were removed by using a needle and syringe from each tube and the optical density (OD) at $535 \mathrm{~nm}$ was determined following the colorimetric reaction. Sampling and OD determination were undertaken again after the tubes had been incubated for 8 days at $39^{\circ} \mathrm{C}$.

To determine whether DHP was being ruminally degraded following inoculation of cattle in the field, urine samples were obtained from 6 steers that had been inoculated and fed leucaena for 1 month. These animals were from a commercial property and there were no animals that could be regarded as untreated controls.

The concentration of DHP was determined by comparison of the $\mathrm{OD}$ at $535 \mathrm{~nm}$, following the colorimetric reaction, with a standard curve of OD 535 of known mimosine concentrations.

\section{DNA extraction, PCR amplification, and DNA sequence analysis}

To detect the presence of Synergistes jonesii in the inoculum a qualitative PCR technique was developed.

Samples of fermentor liquor $(1 \mathrm{~mL})$ were collected in microfuge tubes and centrifuged at $12000 \mathrm{G}$ for $15 \mathrm{~min}$ (IEC MicroMax, International Equipment Company, Needham Hts, MA, USA). The supernatant was discarded and the bacterial pellet frozen at $-20^{\circ} \mathrm{C}$ prior to DNA extraction. Extraction of DNA was by physical disruption using a bead beater (Mini-Beater; BioSpec Products, Bartlesville, OK, USA) and followed the protocol described by Whitford et al. (1998).

A fragment of the 16S rRNA gene of $S$. jonesii was amplified by PCR. Primers used were 357F 5'-CTC CTA CGG GAG GCA G-3' from a conserved region of the $16 \mathrm{~S}$ rRNA gene as described by Lane (1991), and DHP1017 5'-GCA AGC TAA GGT CCT CTC GA-3', the sequence of which has been shown to be specific for $S$. jonesii 
(McSweeney et al. 1993). The 50- $\mu \mathrm{L}$ reaction mixture contained $1 \mathrm{~mm}$ $\mathrm{MgCl}_{2}, 50 \mathrm{~mm} \mathrm{KCl}, 10 \mathrm{~mm}$ Tris- $\mathrm{HCl}(\mathrm{pH} 8.3), 100 \mu \mathrm{g} / \mathrm{mL}$ of gelatin, $200 \mu \mathrm{M}$ each dNTP (dATP, dCTP, dGTP, dTTP), $0.4 \mu \mathrm{M}$ of each primer (357F and DHP1017), the appropriate DNA template, and 0.8 units Taq DNA polymerase (Boehringer Mannheim, Mannheim, Germany). PCR was performed using a Hybaid PCR Gradient Express Thermal Cycler (Hybaid, Middlesex, UK). An initial heating step at $98^{\circ} \mathrm{C}$ for 2.5 min was performed prior to the addition of the Taq DNA polymerase to avoid non-specific amplification of DNA. The cycling parameters for optimisation were: denaturation at $93^{\circ} \mathrm{C}$ for $1 \mathrm{~min}$, annealing at $50-65^{\circ} \mathrm{C}$ (across the gradient block) for $45 \mathrm{~s}$, and extension at $72^{\circ} \mathrm{C}$ for $2 \mathrm{~min}$, these 3 steps being repeated for 30 cycles. This was followed by a final cycle with an extension step at $72^{\circ} \mathrm{C}$ for $10 \mathrm{~min}$. Amplification products were detected by horizontal gel electrophoresis of a $5-\mu \mathrm{L}$ aliquot in a $1 \%$ agarose gel in Tris-borateEDTA (TBE), followed by ethidium bromide staining and visualisation under UV light. A $1 \mathrm{~kb}$ Ladder (Gibco BRL, Life Technologies, Gaithersburg, MD, USA) was included on each gel to enable confirmation of the size of the amplified product. PCR products were purified using the QIAquick PCR Purification Kit (QIAGEN GmbH, Hilden, Germany) as per the manufacturer's instructions.

Sequencing was performed using the ABI Prism Dye Terminator Cycle Sequencing Ready Reaction Kit with Amplitaq DNA Polymerase FS and a model 373A DNA sequencing system (PE Applied Biosystems Inc., Foster City, CA, USA). All procedures were performed according to the manufacturer's protocols. The primer used for sequencing was 530F (Lane 1991). Sequence fragments were checked manually using Sequence Navigator (PE Applied Biosystems Inc., Foster City, CA, USA). The Gapped BLAST database search program (Altschul et al. 1990) at the National Centre for Biotechnology Information (NCBI) was used to confirm sequence identity.

\section{Results}

\section{Production and use of the fermentor-derived inoculum}

Production of the inoculum began in 1995 and 18 batches (235 bottles) of inoculum have been produced. Since the inoculum has been in use, sufficient has been produced to protect 11750 cattle from mimosine and DHP intoxication while feeding on leucaena (unpubl. data).

Over this period of time there has been no indication, through informal producer feedback, that the inoculum has failed to protect animals. There have been no reports of clinical symptoms typical of mimosine or DHP intoxication in herds where cattle had received the inoculum.

\section{Mimosine and DHP degradation}

The results of the experiment to test the ability of fermentor liquor to reduce mimosine (and DHP) concentrations in vitro are presented in Fig. 2. The concentration of mimosine/DHP was markedly reduced in all of the tubes following incubation for 8 days at $39^{\circ} \mathrm{C}$.

The average OD 535 of the urine samples from 6 steers in a commercial herd was $0.122 \pm 0.038$ or $<0.5 \mathrm{~g} \mathrm{DHP} / \mathrm{L}$.

\section{PCR detection of $\mathrm{S}$. jonesii}

The optimum annealing temperature for the PCR reaction was $58^{\circ} \mathrm{C}$. PCR amplification of total bacterial DNA extracted from fermentor liquor samples, using a universal

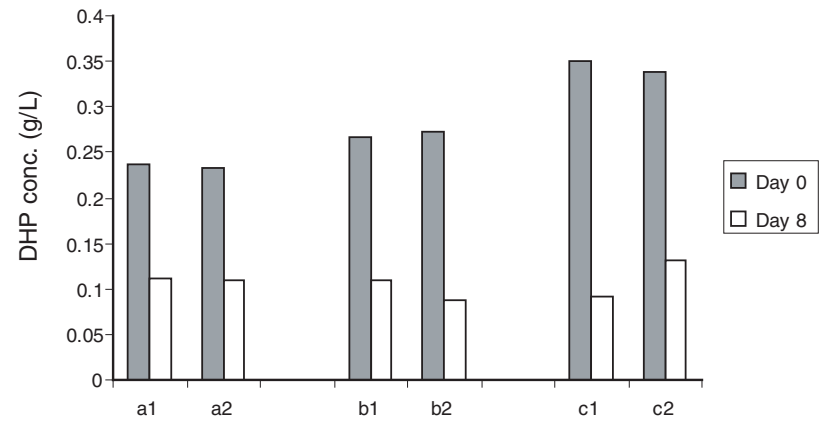

Fig. 2. In vitro disappearance of mimosine/DHP in fermentor liquor following 8 days incubation, post-fermentation, as measured by colorimetric assay (Allison et al. 1990), at an optical density of $535 \mathrm{~nm}$. Tubes a1 and a2 contained fermentor liquor only; residual mimosine/DHP from the fermentation is evident at Day 0. Tubes b1 and b2 were as for a 1 and a 2 except that $1 \mathrm{~mL}$ of a $5 \mathrm{~mm}$ solution of mimosine had been added immediately before measuring OD at Day 0 . Tubes c1 and c2 were the same again except $1 \mathrm{~mL}$ of $15 \mathrm{~mm}$ mimosine was added at Day 0 .

bacterial primer (357F) and the specific $S$. jonesii primer (DHP1017), resulted in a product of 678 bp in length (Fig. 3). A product of this size was predicted to be amplified from the $S$. jonesii $16 \mathrm{~S}$ rRNA gene. When these same primers were used to amplify DNA extracted from a sample of rumen contents from a steer grazing Rhodes grass pasture, which was unlikely to have a resident $S$. jonesii population, no product was observed. The latter DNA was shown to be amplifiable by PCR by using the universal primers $27 \mathrm{~F}$ and 1525R of Lane (1991).

To confirm that the product formed, when the specific $S$. jonesii primer was used, was from $S$. jonesii, the DNA sequence of a $483 \mathrm{bp}$ portion of the PCR product was

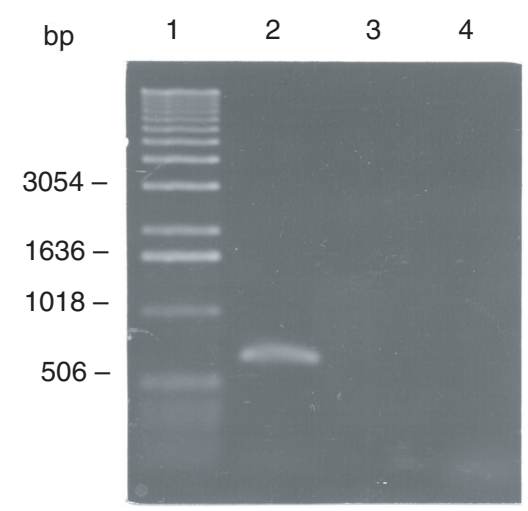

Fig. 3. Agarose gel electrophoresis of PCR products following amplification with $S$. jonesii-specific primers. Lane 1, $1 \mathrm{~kb}$ ladder, DNA size marker; Lane 2, PCR using DNA from bacteria in the fermentor liquor; Lane 3, PCR control with no DNA; Lane 4, PCR using DNA from ruminal bacteria from a pasture-fed steer 
sequenced and compared with sequences stored by Genbank. The product was found to be $98 \%$ similar to the corresponding region of the $16 \mathrm{~S}$ rRNA gene of S. jonesii. With a single exception, mismatches between the PCR product and known $S$. jonesii DNA sequence were due to ambiguous bases in the known sequence.

\section{Discussion}

An in vitro, fermentor-based inoculum to deliver $S$. jonesii to beef cattle being fed leucaena, and methods for storage and delivery, have been developed. We chose to use a mixed bacterial inoculum from animals previously adapted to leucaena rather than a pure culture of $S$. jonesii. Although a single strain of $S$. jonesii is capable of degrading mimosine and DHP (Allison et al. 1990, 1992; McSweeney et al. 1993), several genetically related strains have been isolated and it has been suggested that a combination of strains may be more efficient at degrading mimosine and DHP than the individual strains (C. S. McSweeney, pers. comm.).

The ability of $S$. jonesii to compete, maintain viable populations, and degrade mimosine/DHP, with continued passage through the fermentor, was evident from the breakdown of mimosine in vitro, the lack of signs of intoxication in inoculated animals, low urinal DHP in inoculated cattle, and the continued presence of $S$. jonesii, as indicated by PCR. The use of macerated leucaena leaf as the sole source of nutrient in the fermentor has probably contributed to the continuing survival of the $S$. jonesii population by maintaining a selection pressure that favours this bacterium, as is the case when leucaena is fed to cattle (Quirk et al. 1988, 1990; Hammond 1995).

The urinal DHP concentration of inoculated cattle from a commercial herd that had been continuously grazing leucaena for 1 month after inoculation was very low compared with published data (Jones 1981; Allison et al. 1990). Unfortunately, as the samples were from commercial cattle, no control animals were available for comparison, and as the samples supplied were one-off, it was not possible to determine daily DHP excretion rates. However, Jones (1981) determined the DHP concentration in the urine of cattle grazing leucaena in Hawaii, which he regarded as being able to degrade mimosine and DHP in a similar manner to goats, and found concentrations of DHP between 0.67 and $0.31 \mathrm{~g} / \mathrm{L}$. This concentration, regarded by him at that time to be very low, is considerably more than measured in the current study.

Difficulties were experienced with the use of the colour reaction for mimosine/DHP degradation (Allison et al. 1990) as a routine method to indicate the presence of $S$. jonesii. The slow rate of degradation of mimosine, also demonstrated by Jones and Megarrity (1986) and Allison et al. (1990), and daily addition of mimosine-rich leucaena leaf meant that determining the degradation of mimosine and DHP during the course of a fermentor run was problematic. Postfermentation degradation was also slow and we believe not completely reliable, possibly due to other plant-derived compounds, particularly phenolics, interfering with optical density readings. Due to the possibility of inaccuracies with the use of the colorimetric method, as a routine measure of the presence of $S$. jonesii in fermentor liquor, it was decided to directly determine the presence of $S$. jonesii using PCR.

The use of a primer with a DNA sequence specific to S. jonesii (McSweeney et al. 1993) and coupled with a universal bacterial domain primer (Lane 1991) made it possible to amplify a specific section of the 16S rRNA gene of $S$. jonesii. This PCR assay has successfully detected the presence of $S$. jonesii in the mixed bacterial population of the fermentor. If a quantitative assessment of population density was to be required in the future, a Real-Time PCR or competitive PCR could be developed based on the current method. However, we do not feel that this is required for the current application.

An important aspect of the use of the inoculum has been its ability to be stored at $-20^{\circ} \mathrm{C}$. By adapting basic methodology for the laboratory storage of rumen bacteria and the storage of field samples of rumen contents (Teather 1982; Klieve et al. 1998) it is possible to store the inoculum in a viable state at $-20^{\circ} \mathrm{C}$. This enables field stations and producers to store the inoculum in a domestic freezer, until required, when it is then thawed and administered to cattle. The inoculum is distributed from Brian Pastures Research Station and is sent to beef cattle producers by courier on wet ice. Once inoculum is thawed, we recommend immediate use. We also recommend that $100 \mathrm{~mL}$ of inoculum be administered, using a conventional drench gun, to 1 in every 10 cattle in the herd.

To our knowledge this is the first live, anaerobic, bacterial inoculant (probiotic) in Australia that has been produced and stored in vitro for use with commercial cattle. It is suggested that this technology could be applicable to the production and delivery of other live bacterial inocula for use in animal agriculture in Australia.

\section{Acknowledgments}

We thank Dr C. McSweeney for useful discussions regarding the biology of $S$. jonesii, and G. Heck for technical assistance. This work was funded within the Department of Primary Industries, Queensland.

\section{References}

Addison KB, Cameron DG, Blight GW (1984) Effect of leucaena and peanut meal supplements fed to steers grazing native pasture in sub coastal south-east Queensland. Tropical Grasslands 18, 121-130.

Allison MJ, Hammond AC, Jones RJ (1990) Detection of ruminal bacteria that degrade toxic dihydroxypyridine compounds produced from mimosine. Applied and Environmental Microbiology 56, 590-594.

Allison MJ, Mayberry WR, McSweeney CS, Stahl DA (1992) Synergistes jonesii, gen. nov., sp. nov.: a rumen bacterium that 
degrades toxic pyridinediols. Systematic and Applied Microbiology $15,522-529$.

Altschul SF, Gish W, Miller W, Myers EW, Lipman DJ (1990) Basic local alignment search tool. Journal of Molecular Biology 215, 403-410.

Hammond AC (1995) Leucaena toxicosis and its control in ruminants. Journal of Animal Science 73, 1487-1492.

Hegarty MP, Court R, Christie GS, Lee CP (1976) Mimosine in Leucaena leucocephala is metabolised to a goitrogen in ruminants. Australian Veterinary Journal 52, 490.

Hegarty MP, Court RD, Thorne PM (1964) The determination of mimosine and 3,4-dihydroxypyridine in biological material. Australian Journal of Agricultural Research 15, 168-179.

Jones RJ (1981) Does ruminal metabolism of mimosine explain the absence of Leucaena toxicity in Hawaii? Australian Veterinary Journal 57, 55-56.

Jones RJ, Megarrity RG (1986) Successful transfer of DHP-degrading bacteria from Hawaiian goats to Australian ruminants to overcome the toxicity of leucaena. Australian Veterinary Journal 63, 259-262.

Klieve AV, Holroyd RG, Turner AF, Lindsay JA (1998) Rumen bacterial and protozoal populations in cattle being relocated in tropical Queensland. Australian Journal of Agricultural Research 49, 1153-1159.

Klieve AV, Hudman JF, Bauchop T (1989) Inducible bacteriophages from ruminal bacteria. Applied and Environmental Microbiology 55, 1630-1634.

Lane DJ (1991) 16S/23S rRNA sequencing. In 'Nucleic acid techniques in bacterial systematics'. (Eds E Stackebrandt, M Goodfellow) pp. 115-175. (Academic Press: Chichester)

McSweeney CS, Mackie RI, Odenyo AA, Stahl DA (1993) Development of an oligonucleotide probe targeting 16S rRNA and its application for detection and quantitation of the ruminal bacterium Synergistes jonesii in a mixed-population chemostat. Applied and Environmental Microbiology 59, 1607-1612.
Miller SM, Klieve AV, Plumb JJ, Aisthorpe R, Blackall LL (1997) An in vitro cultured rumen inoculum improves nitrogen digestion in mulga-fed sheep. Australian Journal of Agricultural Research 48, 403-409.

Quirk MF, Bushell JJ, Jones RJ, Megarrity RG, Butler KL (1988) Liveweight gains on leucaena and native grass pastures after dosing cattle with rumen bacteria capable of degrading DHP, a ruminal metabolite from leucaena. Journal of Agricultural Science, Cambridge 111, 165-170.

Quirk MF, Paton CJ, Bushell JJ (1990) Increasing the amount of leucaena on offer gives faster growth rates of grazing cattle in south east Queensland. Australian Journal of Experimental Agriculture 30, 51-54.

Shelton HM (1998) The Leucaena genus: new opportunities for agriculture (a review of workshop outcomes). In 'Leucaenaadaptation, quality and farming systems'. (Eds HM Shelton, RC Gutteridge, BF Mullen, RA Bray) pp. 15-24. (Australian Centre for International Agricultural Research: Canberra)

Teather RM (1982) Maintenance of laboratory strains of obligately anaerobic rumen bacteria. Applied and Environmental Microbio$\log y$ 44, 499-501.

Whitford MF, Forster RJ, Beard CE, Gong J, Teather RM (1998) Phylogenetic analysis of rumen bacteria by comparative sequence analysis of cloned 16S rRNA genes. Anaerobe 4, 153-163.

Wildin JH (1985) Leucaena - a permanent dry season forage in Australia. In 'Proceedings of the 15th International Grassland Congress, Kyoto, Japan'. pp. 1301-1302. (Science Council of Japan and Japanese Society of Grassland Science, Nishi-nasuno: Tochigi, Japan)

Manuscript received 24 August 2000, accepted 10 August 2001 